\title{
"I'm not against online teaching, but what about us?": ICT in Ghana post Covid-19
}

\author{
Michael Agyemang Adarkwah ${ }^{1}$ (D)
}

Received: 5 June 2020 / Accepted: 9 September 2020 / Published online: 16 September 2020

(C) Springer Science+Business Media, LLC, part of Springer Nature 2020

\begin{abstract}
Globally, Information and Communication Technology (ICT) is regarded as a dependable vehicle for facilitating educational reform and development, a platform for communication, and as a means to achieve the Sustainable Development Goal Four (SDG 4). Since the enactment of the No Child Left Behind Act (NCLB) and declaration of the SDG 4, many countries have opted to embrace the lifelong education for all by integrating ICT in teaching and learning at all school levels. The Ghanaian Government's initiative to ensure "education anytime anywhere for everyone" by revolutionizing teaching and learning through ICT has faced a lot of challenges and criticisms. The main mission of the Ghana ICT for Accelerated Development (ICT4AD) in 2003 was to transform Ghana into an information and technology-driven high-income economy through education, but this goal is yet to be realized. In the wake of the COVID-19 which has forced many countries and educational sectors to adopt online learning, there is a need to discuss the effectiveness of online learning and barriers to online learning in the developing contexts, and how to successfully integrate ICT in schools for online learning, especially rural schools where students' educational careers are in jeopardy because they benefit less from online learning. The paper identifies critical factors that affect online learning, recommends post COVID-19 strategies to promote e-learning for policymakers in education and the government, and concludes with a conceptual model for emergency transition to elearning.
\end{abstract}

Keywords Online learning · E-learning · ICT · ICT integration · Distance education · Ghana

Michael Agyemang Adarkwah adarkwahmichael1@gmail.com

1 Southwest University, No. 2, Tianzhu Street, Beibei District, Chongqing, China 


\section{Introduction}

Online learning is hailed as an essential force in democratizing education (Jones 1997). It is a way of opening education to populations who had restricted access because of geography, status or physical handicap (Carr-Chellman 2005). Khan (1997) defines it as an innovative method to instruct students in remote areas, which involves all types of learning that is done using the computer or other ICT resources. Since the term was first introduced in 1995, it is used as an overlapping concept with blended learning, elearning, online courses, and online or distance education (Singh and Thurman 2019). The advancement of ICT has called for online learning as a feasible and economically appropriate means of extending quality higher education (Asunka 2008). The role of ICT in education, specifically higher education, cannot be downplayed, it is beneficial for teachers and students (Aljaraideh and Bataineh 2019). However, the challenge associated with online learning is the access to ICT resources because online learning thrives on the availability of ICT facilities (Arthur-Nyarko and Kariuki, 2019, b). There is an uneven spread of access to ICT among different populations, households, and spaces because network is not the same everywhere (Lembani, Gunter, Breines, Tapiwa, \& Dalu, 2019).

The significant role ICT plays in the development of any nation has called for countries to produce ICT literate citizens (Crisolo, 2018). ICT has gained a solid reputation in the education systems of both developed and developing countries (Law, Pelgrum, \& Plomp, 2008). ICT in education can provide the twenty-firstcentury skills needed to adapt and compete in this knowledge and information society (Haji, Moluayonge, \& Park, 2017). According to the authors, ICT in education enhances student learning, provides education to students with no or limited access to education, aid in facilitating the training of teachers, and enhances the skilled workforce and promote social mobility. ICT is also considered as essential for quality higher education (Liebenberg, Chetty, \& Prinsloo, 2012). ICT has the ability to enhance learning, make a subject appealing, facilitate problem-solving, communication, research skills, and decision-making process (Hong, 2016). Waluyo (2019) adds that ICT is a positive predictor of the academic achievement of students in mathematics, science, and reading. ICT also facilitates teaching and e-learning, which ultimately have a positive effect on teaching, learning, and research activities.

A general assumption is that for Ghana to meet economic, social, and political global demands, ICT should be prioritized. In light of this, The Ministry of Education of Ghana introduced the "one laptop, one student" policy where 1,000 laptops were dispensed to 30 schools (three schools in each region) across the country (Education Sector Performance Report, 2010). Another 60,000 laptops were also purchased to be distributed to 2500 junior high schools (Education Sector Performance Report, 2012). According to Amanortsu, Dzandu, \& Asabere (2013), most of the government initiatives to ensure quality and accessible ICT education for all in Ghana has failed to achieve its goals. For example, Agyemang \& Dadzie (2010) found in their study that a policy statement for supplying ICT based-support for Distance Education (DE) learners were available but were yet to be implemented. The integration of ICT in teaching and learning is still at the early stage in the education systems of most developing countries (Antwi, Bansah, \& Franklin, 2018). Over a decade ago, Ghana introduced DE as a means to provide learners with access to quality education and promote human 
resource development (Addah, Kpebu, \& Kwapong, 2012). One of the major challenges in the Ghanaian education system is the inequality of educational resources which includes usage of computers and other ICT materials (Buabeng-Andoh, 2012). Antwi et al. (2018) mentioned that the provision of ICT in secondary schools for learning is skewed towards schools categorized as premier ("A") schools and located in urban areas. Also, at the primary level, provision of ICT is also skewed towards private schools (Ayebi-Arthur, Aidoo, \& Wilson, 2009). Governments should fund ICT projects that emphasizes on the needs, capacities, perspectives, and aspirations of the greater number of people living in rural areas (David, 2009). The main objective of the study is to provide possible solutions for successful transitioning, implementation and sustenance of e-learning programs. The paper first identifies the e-learning challenges in the Ghanaian context based on respondent's views and then provide strategies for smooth delivery of e-learning derived from extant literature The research questions leading this investigation are; what are the perceived effectiveness of the online learning, what are the perceived barriers to online learning and what are the perceived strategies for a successful ICT integration in education for students who are unable to partake in e-learning process because of environmental and contextual factors related to ICT in lieu of the COVID-19 crisis. There are limited studies that thoroughly examines the effectiveness of and barriers to the online learning, and identify critical contextualized factors to enhance online learning in developing countries like Ghana since the inception of the COVID-19.

\section{Background context}

The Government of Ghana has invested several resources and initiated many promulgated policies to ensure ICT is accessible to every student in Ghana because of its pivotal role in education. The first governmental policy on ICT was the ICT for Accelerated Development (ICT4AD) in 2003 which outlined a framework that sought to transform Ghana into an information and knowledge-driven ICT literate nation (Ministry of Education, 2015). This policy was reviewed twice (in 2006 and 2008) until a revised policy document was made available in 2009. The main goal of the revised version was to facilitate the integration, utilization, and modernization of ICT in schools in Ghana. It was proposed that ICT should be integrated as a core subject, an elective subject, and as a teaching tool for all other subject areas. The policy highlighted that ICT access and literacy is low in Ghana. One of the main goals of the 2007 educational reforms is to ensure that all students in Ghana in the pre-tertiary institutions acquire basic ICT literary skills (which also include the use of internet), and apply the skills in their studies and in their daily activities (Mereku, Yidana, Hordzi, Tete-Mensah, \& Williams, 2009). A survey of 20 lecturers and 105 students in Accra Polytechnic revealed that access to ICT facilities was inadequate, time to access ICT was inadequate, and there was little use of ICT software (Amanortsu, Dzandu, \& Asabere, 2013). Another study in Ghana found that $60 \%$ of the respondents teaching ICT in the early years of school had knowledge about ICT, and $67 \%$ of the teachers did not integrate ICT in their teaching (Asante, 2014). Boni (2018) in his study concluded that both teachers and students in Ghana lacked the efficacy and creativity in using ICT for teaching and learning. MubashirAhmed (2009) attributes the the challenges associated with ICT integration in Ghanaian 
schools to lack of internet access, lack of quality teachers, insufficient number of computers, high cost of ICT gadgets, and lack of electric power in some communities. Another study in Ghana revealed that access to electricity is a major factor affecting online learning in the country (Arthur-Nyarko and Kariuki, 2019, b). Despite the unprecedented efforts by successive governments to ensure ICT is integrated in teaching and learning, the process have been fraught with a lot of challenges in Ghana, especially in the rural areas. Ghana ranked 112th among 175 countries in the global ICT development index in 2016 after being ranked 123rd in 2014 (International Telecommunication Union, 2014; International Telecommunication Union, 2016).

\section{Statement of the problem}

In lieu of the COVID-19 crisis, the government of Ghana announced the suspension of all school operations both pre-tertiary and tertiary on March 15, 2020, as parts of the efforts to stop the spread of the virus (Cromwell, 2020). The closure of universities and schools have disrupted the learning of students and have deprived students opportunities for growth and development (UNESCO, 2020). Digital learning emerged as an ultimate response to the disruption in education due to the COVID-19 lockdown of schools. Since the lockdown, the government of Ghana has considered the possibility of initiating online courses for students. Instead of been proactive in ensuring rigorous implementation of online teaching and learning, the education system was stagnant until it was prompted by the COVID-19 crisis. The Minister of Education, Matthew Opoku Prempah announced that the Center for National Distance Learning and Open Schooling (CNDLOS) has rolled out an online platform that will make core content accessible to all students in the Senior High School (SHS) level. He further declared that the Ministry had plans in place to broadcast more contents to the Junior High School (JHS) and upper primary students. However, the National Union of Ghana Students (NUGS) has petitioned the government to halt all online academic activities launched in the universities across the country (Anyorigya, 2020). The NUGS referred to the online learning as "challenge-ridden online learning". The association cited inadequate bundle incentives for schools (lecturers and students), lack of properly laid framework for the implementation of online learning, and the plight of needy students who have been left out of the online learning platforms because of their inability to settle school bills. Another concern raised by the NUGS is the possibility of compulsory exams and assignments on e-learning platforms that will disadvantage students who are unable to participate in the online learning because of factors beyond their control. Online learning in SubSaharan Africa is a great challenge because it relies on the availability of ICT facilities (Asunka, 2008). According to the UNESCO (2012), there is a gap between the availability of ICT infrastructure and the capability of agrarian communities to integrate ICT to boost the economy. Also, the report mentioned that African universities and teacher education institutions do not have the adequate ability to help integrate ICT in schools. With the limited access to ICT resources and institutional challenges in its implementation in Sub-Saharan countries such as Ghana, there is a need for the government and education sectors across the country to address contextual and environmental difficulties faced by needy and rural school students who are excluded from the e-learning platforms which are no fault of theirs. 


\section{Literature review}

\subsection{Effectiveness of e-learning program}

E-learning is beneficial (Arthur-Nyarko and Kariuki, 2019, b), but its effectiveness is contextualized (Lembani, Gunter, Breines, Tapiwa, \& Dalu, 2019). Students from developing countries score lower in online learning and are likely to withdraw from the online courses compared to their colleagues in developed countries (Kizilcec \& Halawa, 2015). In the US, a meta-analysis of existing data revealed that students engaged in online learning performed better than those in face-to-face sessions while students who blended online and traditional learning performed the best of all (The Council of Independent Colleges, 2016). A student may be part of the online learning but may not actively use the service or follow the tutor (Bean, et al., 2019).

\subsection{Barriers to e-learning program}

Barriers identified in literature include; high cost, inadequate infrastructure, lack of ICT skills, rejection of e-learning by faculty members, and lack of accessibility to quality internet connection and electricity.

Start-up cost for online learning may be expensive (Queiros \& de Villiers, 2016). The high cost of purchasing ICT equipment affect the adoption of online learning (Sinha \& Bagarukayo, 2019). Technology and gadgets needed to make learning effective may not be cheap, affecting the online process negatively (Srichanyachon, 2014). Limited funding can affect institutions from hosting online learning (Bean, et al., 2019). Online education may cost more to develop and deliver than face-to-face courses (Turk \& Cherney, 2016).

In Tanzania, $68 \%$ of teachers declared they lacked access to computer, while $73 \%$ revealed they experienced low internet bandwidth (Mtebe \& Raisamo, 2014). Teaching and learning can take place at anywhere and at anytime with the help of ICT tools (Cradler \& Bridgforth, 2002). Inadequate access to technology, studying materials and computers can leave students marginalized and anxious, which affect the online learning process (Queiros \& de Villiers, 2016). Asunka (2008), he concluded that only 5 out of 22 students had access to computer and internet connectivity at home.

Lack of technology skills and inadequate background experience with online learning are constraints to online education (Olesova, Yang, \& Richardson, 2011). Tutors ought to have required advanced technological skills which sometimes require schools to hire tutors from outside companies who already have the skills (Bean, et al., 2019). Lack of experience with online teaching is a barrier to organizing online education (Luongo, 2018). Students who do not have prior knowledge and experience in online learning sometimes also lack technical assistance and support systems (Srichanyachon, 2014). According to Mtebe \& Raisamo (2014), 63\% of teachers engaged in online learning in Tanzania lacked the skills needed to create or use online educational resources.

Most faculty members reject online learning as alien to them and are skeptical about it (Bacow, Bowen, Guthrie, Lack, \& Long, 2012). Some faculty members also consider developing online courses as time consuming in comparison to traditional methods of teaching (The Council of Independent Colleges, 2016). Hesitance by faculty members to teach online courses and their lack of acceptance of online instruction is a perceived barrier to online learning (Turk \& Cherney, 2016). 
Slow and unreliable network connections affect the quality of online learning (Bean, et al., 2019). Instructions can be delayed as a result of poor internet connections (Srichanyachon, 2014). In the study. Limited internet access which includes poor internet connection and low speed demotivate institutions for pursuing online education (Sinha \& Bagarukayo, 2019). Rural communities involved in online learning find it difficult to fund and attract qualified teachers to instruct advanced courses (de la Varre, Keane, \& Irvin, 2010). Lack of internet access and computers in homes in rural areas affect the progress of online learning (DePaul, 2020). Lack of constant supply of electricity and internet access in rural communities also makes it difficult to assimilate the online education process (Ivala, 2013).

\subsection{ICT integration for e-learning}

In education, ICT integration involves many interrelated factors such as curriculum, teacher characteristics, training and development, infrastructure, organisational factors like school leadership, school culture and supportive framework (Judge, 2013). ICT integration concerns with the application of technology to aid student learn traditional academic subjects (Grabe \& Grabe, 2007). According to the authors, successful ICT integration has transformed communities and shaped their lives and thoughts. In 2005, the British Columbia Ministry of Education announced the integration of ICT in Kindergarten to Grade12 throughout the country to ensure that the education system remains important and actively engage students (Birch \& Irvine, 2009). Successful integration of ICT in schools still face myriads of obstacles (Hew \& Brush, 2007). Integration of ICT in developing countries is still a challenge (Aksal \& Gazi, 2015). One of the first steps to ensure successful ICT integration is to consider the structural (availability of resources and classroom space, availability of ICT support and maintenance) and cultural (mission and vision of the school for ICT integration) elements of the school where ICT is being integrated (Tondeur, Devos, van Houtte, van Braak, \& Valcke, 2009). Bingimlas (2009) outline some necessary steps to ensure successful ICT integration; provision of ICT resources (both hardware and software), training new pedagogical approaches to faculty members resistance to change, provision of training courses on how to deal with new gadgets and modern technologies, providing sufficient time for daily lessons, and provision of continual reliable technological support. Sarkar (2012) lists the critical elements for to be considered during the implementation of ICT in learning; leadership issues, equitable distribution of ICT resources and sustainability, and financial issues.

\section{Research method}

The study adopted a qualitative method using a narrative inquiry approach to explore the perceptions of students on online learning in Ghana and how to successfully integrate ICT in education to improve online learning for students, especially those in urban poor and rural areas in Ghana. In a qualitative study, a central phenomenon is the process, key concept or idea that is studied, and a researcher learns more from participants through exploration (Creswell, 2018). Data was collected through interviews. A list of post-COVID-19 strategies was formulated from extant literature based on respondents' views. 


\subsection{Instrument}

The researcher used a semi-structured interview guide comprising of a list of prepared questions related to the research questions to conduct the interview. The instrument was prepared based on recurring themes in extant literature and was screened for accuracy and validity by a researcher in Ghana. This allowed the researchers to ask open-ended questions to ensure respondents give their broad perspective about the topic of the study. Interviews allow a researcher to probe and get an in-depth meaning of the feelings, perceptions and attitudes of participants (Gaffas, 2019).

\subsection{Population and sampling}

All tertiary students from urban poor and rural areas who took part in the online learning in Ghana formed the target population. Fifteen (15) of the students were randomly selected to be part of the study. Five (5) students were taken each from the 3 most cosmopolitan regions in Ghana (Greater Accra, Ashanti region, and Central region) to make up the total sample of the study. The student came from the universities, teacher and nursing training schools in the country (Table 1).

\subsection{Procedures}

Students from the tertiary institutions in Ghana who were taking part in the online learning in Ghana were recruited to find answers to the research questions. An introductory letter was sent to the randomly selected students about the purpose of the study and to seek their consent to be part of the study. After the consent of the study respondents were gained, the researcher scheduled an appointment with each of the participants to conduct the interview. All interviews were conducted in English using the "WhatsApp" application.

\subsection{Data analysis}

The researcher transcribed the recorded interviews verbatim and the data was analyzed into themes and sub-themes using the NVivo 11.0 software. The interviews were

Table 1 Demographic characteristics of participants

\begin{tabular}{ll}
\hline Personal Information & Number \\
\hline Gender & \\
Male & 9 \\
Female & 6 \\
Total & 15 \\
Educational level & \\
University & 10 \\
Teacher training & 3 \\
Nursing training & 2 \\
Total & 15 \\
\hline
\end{tabular}


replayed severally to ensure the accuracy of the transcription. The researcher used pseudonyms for each of the participants to ensure confidentiality.

\section{Results and discussion}

Almost all the barriers associated with e-learning in literature reviewed earlier were prevalent in the Ghanaian context (see Table 2). The findings of the interviews conducted suggest that the online learning in Ghana is not effective enough and is also fraught with a lot of challenges. The section concludes with innovative and some novel solutions found in extant literature to the problems identified in the study and a conceptual framework for transitioning to e-learning.

\subsection{Effectiveness of the online course}

Most of the 10 students interviewed indicated that the online learning is the best alternative approach to teaching and learning during this pandemic. However, because of its spontaneous nature, and not an approach to education carefully thought of my school leaders and the government, they felt the online learning was not effective as they hoped for.

Social interaction An ample amount of the students felt the lack of student-student interaction and teacher-student interaction negatively affected the effectiveness of the course.

"Oh ok, personally, I think this online learning is not that effective. Let me take campus for example, on campus you go for lectures, you meet the lecturer, you will have this interaction, like face-to-face, so that makes you really comprehend what the lecturer is putting across, and aside that you even have the teaching assistants who are willing to help you understand or if you have any difficulty they are able address that issue." [Lucy-University]

Table 2 Qualitative themes (categories) and sub-themes (subcategories) of interview guide responses

\begin{tabular}{ll}
\hline Themes & Sub-themes \\
\hline $\begin{array}{l}\text { Effectiveness of the } \\
\text { Online course }\end{array}$ & $\circ$ Social interactions \\
& $\circ$ Student outcomes \\
& $\circ$ Communication \\
& $\circ$ Traditional versus Online approach \\
& $\circ$ Cost \\
& $\circ$ Online platform \\
& $\circ$ Study materials \\
& $\circ$ ICT tools \\
& $\circ$ Prior knowledge \\
& $\circ$ Internet access \\
& $\circ$ Electricity \\
& $\circ$ Education \\
& $\circ$ Provision of ICT tools \\
& $\circ$ Internet Bandwidth \\
& $\circ$ Motivation \\
& $\circ$ School leadership practices
\end{tabular}


Student outcomes Only few of the students believed students' outcomes in the online learning would be better than the traditional approach. Many believed that the difficulty with internet access and network challenges will result in a negative effect on the outcomes

"The student outcome of online learning as compared to the traditional approach is very sad and heartbreaking. Let me take the quiz for example, you will take a quiz online, and the system gets jammed, you've really learnt, not that you didn't learn, you've really learnt, and you go, and you're able to answer the questions, let me say if it is out of 20 , you are able to get 15 or 10 correct, and then you get an F, it just saddens my heart" [Ellen-University]

Communication Some of the students were of the view that sometimes communication between teacher and students is not possible because the e-learning system can go off for a while before it starts functioning.

"The intercommunication between lecturers and students is very poor. Communication is not good. You will be having a class, and then the network starts misbehaving, meanwhile, the teacher is talking! How do you retrieve the words he has already said? What if the words he has said is the stepping stone to understand the next sentences?" [Sandra-Nursing training]

Traditional versus online approach More than half of the participants interviewed believed that the traditional approach to teaching and learning is more suitable for them as compared to the online learning they were experiencing.

"Ok, What I can say is my university, for example, am reading Chinese and political science, so with Chinese the lecturer is supposed to write down the characters on the whiteboard for us to really eerrm know the stroke orders. Also, there are instances that you need you need to even, eerrm for Chinese oral you need to listen to the lecturer, like look at the lecturer's mouth, the expression that she makes for you to be able to understand whatever she is saying. So I think I prefer the marker-board because taking my course, for example, it really helps, yes." [Ellen-University]

\subsection{Barriers to online learning}

Cost One of the major challenge mentioned by almost all of the participants was the financial commitments they have to make to ensure they actively take part of the course. According to the students, the online method of learning was expensive than the traditional approach to learning they experienced.

"Online learning is quite expensive. So far the has given us a data SIM which gives us 1.5 gigabytes every month. But the problem is, this bundle is just 
something small. It doesn't get us anywhere. I remember my first zoom class was not more than 30 minutes, and 400 megabytes was already gone." [Ted-University]

Online platform Persistently, the students lamented about the breakdown of the online platform.

"With the accessibility to the online platform, I think with that is okay. Sometimes you log in, and the site just jams, so that really hurt and when you have quiz to take, and you log in and the system jams and just log you out of the system." [Paul-University]

Study materials The students believed that study materials were readily available to download at any time.

"Oh okay, every course has its learning materials on the site provided they have not given us already" [Ted-University]

ICT tools A considerable amount of the respondents asserted that ICT tools were not given to them prior learning. Every student had to get an ICT tool for himself/herself to engage in the online mode of delivery.

"We use our own ICT tools, like phones and laptops. The school does not provide us with ICT tools. If you don't have these ICT tools, you have to share that of a friend." [Joe-University]

Prior knowledge Most of the participants had little exposure to online mode of learning prior to their current online method of learning.

"Mmmm as for background knowledge I don't have much experience but per our experience of sending messages through e-mail and using other platforms to send documents that is what helped us in using the online learning platform, since we couldn't have an orientation on how to engage in e-learning." [Bright- teacher training]

Internet access Accessing the internet was one of the major challenges students mentioned.

"Good internet access is a huge challenge. So most of the students we adopted that midnight is when we will log into the online learning site to download and upload materials. It is effective as compared to the normal day hours. However, this has affected our sleep" [Paul-University] 
Electricity There were mixed views on the availability of electricity for the online learning. Some believed lack of electric power affected their learning while others were okay with it.

"Hmmm electricity is another impediment. Recently our transformer got spoilt, and it took almost two weeks for the local government to fix it. Meanwhile, tests and studies were ongoing." [Mercy_-University]

\subsection{ICT integration}

Education Many students indicated orientation of teachers and students on ICT for teaching and learning is integral for successful integration of online learning in schools.

"For me, I think it is not only students who have to be educated on e-learning. My brother is not ICT teacher and has no special skills in ICT, but he is also supposed to use online learning platforms. He likes to use social media than to use the online platform for sending documents." [Ted-University]

Provision of ICT tools Some students called for the provision of ICT tools for schools and students who can't afford the tools for themselves.

"The government should provide laptops to students in the middle or high school so that by that the time the student comes to the tertiary level, he or she has a laptop and can have access to many things online." [Joe-University]

Motivation The students believed the motivation of both teachers and students would improve the online learning.

"Personally, I think the government should motivate teachers and students to engage in the e-learning. E-learning can be effective when there is motivation. The government can give allowances to teachers and reduce our school fees". [Julius-University]

"We students in the rural areas have no joy in this online learning. The challenges are too much. Electricity and internet access are a major problem. If the government wants ICT to be effective, all these problems should be solved." [Prince-Teacher training]

School leadership Students mentioned that school leaders should liaise with the government to improve the online learning. They believed school leaders could act as a channel for their voices to be heard.

"School leaders like principals and VC have to eerrm, we have open forum where students bring their grievances on board, so as the SRC also take eerrm an active 
role in presenting the pleas and plights of students the school authorities, they also have to make the students' grievances known to the government so that the government can put the necessary measures in place to provide the tools that are needed to help the teachers and the students as well.” [Ellen-University]

\subsection{Post Covid-19 strategies to promote E-learning}

Providing electricity Solar power gadgets and human-powered electricity have emerged as a promising solution to the increasing digital divide as a result of lack of electric supply (Wyche \& Murphy, 2013). The authors states that although solar photovoltaic-powered devices can charge mobile phones and some ICT gadgets for e-learning, human-powered electricity are more preferable because human power is abundant worldwide. Human-powered electricity is when human activities such as cranking (by hand) and pedalling (using the legs) are captured to turn a dynamo to generate electrical charges for electronic applications. In Kenya, the researchers found the two models effective for providing micro-electricity for electronic devices. Jimba \& Ogundele (2015) opined that solar power supply, biomass, standby power generators and wind power supply are promising solutions to generating electricity for virtual classrooms in Nigeria. According to the authors, this makes teaching and learning effective without any disruption in power. Hamajoda (2018) is of the same view that solar power supply and standby generators can facilitate e-learning by dealing with the challenges associated with electricity in rural areas.

Fostering acceptance of e-learning Academics are often slow to embrace e-learning but are required to adapt positively to changes resulting from technology (Flavell, Harris, Price, Logan, \& Peterson, 2019), and one of the best ways to foster adaptive learning of technology is to improve instructor and student self-efficacy (Solangi, Shahrani, \& Pandhiani, 2018). Flavell et al. (2019) state that one of the ideal ways to empower academics to be adaptive with e-learning is to engage them in recreational activities such as reading on technological devices for pleasure, playing games, or using social media. This makes users comfortable with the e-learning and also increases their self-efficacy. Media literacy (such as the use of social media) can foster acceptance of e-learning and increase digital literacy (Nowell, 2014). Collaborative e-learning also promotes exchange of experiences and ideas among students, encourage students to work together, develop their academic competence, increase their self-efficacy, develop their social skills and also fosters both their social and cognitive qualities for e-learning (Ngai, Lee, Ng, \& Wu, 2018). A wide range of e-teaching and e-learning methodologies can be introduced to encourage both teachers and students to embrace e-learning such as podcast and vodcast (Uren \& Uren, 2009). Also, to ensure rapid acceptance of e-learning, a clear pedagogical rationale for online teaching which is rooted in instructor's personal philosophy for teaching and learning should be communicated to instructors (Donnelly and O'Rourke, 2007).

User-need analysis for adaptive e-learning Adaptive e-learning has to do with the personalization of e-learning in accordance with individual user's knowledge and behavior, and one way to ensure that is through user-need analysis (Agustini, 2017). 
Developers of e-learning platforms need to perform a user-need analysis; they have to take into account the learning styles of individual learners when creating, selecting, and evaluating e-learning platforms (Muhammad, Albejaidi, \& Akhtar, 2017). According to the authors, user needs can be solicited by employing mix techniques including direct observation, expert review, administering web-based and paper questionnaires, and interviewing teachers and students. Online learning should be planned to meet the learner's expectations (Hachey \& Lachapelle, 2018). Alhabeeb \& Rowley (2018) adds that identifying both student and instructor characteristics for e-learning is a critical success factor for e-learning, "success" for one group does not necessarily connote "success" for another group. Learners on e-learning platforms should be thought of as customers by making it easy to use, making effective use of learner's time, and it has to be attractive and comfortable (Morrison, 2003). Leaner preferences and experiences are integral for a flexible mode of e-learning delivery (Arthur-Nyarko and Kariuki, 2019, b). Teacher's presentations and course materials for e-learning should also be prepared based on students' needs and learning styles (Osubor \& Chiemeke, 2015).

Digital literacy of users The training of digital users is instrumental to ensure the successful transition and integration of e-learning platforms (Muhammad, Albejaidi, \& Akhtar, 2017). Training has been recognized as having a positive influence on the usage of e-learning systems (Solangi, Shahrani, \& Pandhiani, 2018). Training is a critical success factor for e-learning and should be provided for both learners and instructors (Alhabeeb \& Rowley, 2018). Professional development training programs provide teachers with "hands-on" activities, it is essential for them to develop ICT competence and technological pedagogical content knowledge for twenty-first-century learning (Alt, 2018). Course facilitators should be trained on computer literacy and application for effective e-learning (Jimba \& Ogundele, 2015). One way to ensure digital literacy for students is to embed digital literacy skills in the curriculum (Johnston, 2020). School leaders can ensure students develop their own skills by supporting them during orientation activities on technology, peer learning, and encouraging them to use personal technology (Sharpe \& Benfield, 2012). Workshops and training on ICT for e-learning are crucial for users especially teachers, for a flexibility in online delivery (Forsyth, Pizzica, Laxton, \& Mahony, 2010).

Infrastructure support Infrastructure and technical support that provides an opportunity for teachers and students to adopt e-learning should be made available (Solangi, Shahrani, \& Pandhiani, 2018). Availability of telecenters which are equipped with computers and internet connectivity in a poor rural community can help in the integration of ICT in developing countries (Avgerou, 2008). Research findings on ICT in Ghana revealed that institutions engaged in online learning need technology infrastructural support from the government, such as ICT devices (Arthur-Nyarko and Kariuki, 2019, b). The "one student one laptop" policy by the Ghanaian government failed to realize its goal and was an expensive investment. Heeks $(2008,2012)$ argues that mobile devices can now be used to surf the internet and create new content, it could be used as an alternative for poor households in accessing the internet for learning purposes to defray the cost of expensive laptops, mobile technologies can be an alternative. School leaders can lassie with the government to also establish e-learning centers in the various tertiary institutions (Piña, Lowell, \& Harris, 2018). The e-learning 
centers may be staffed with professionals such as technology specialists, media, administrators, and faculty support specialists who provide training support and training for effective engagement with e-learning tools.

Funding Aside fees from students and government which are made available to schools, institutions which are new to online learning can establish e-learning centers and charge some type of fee (convenience fee) or online tuition rate (Piña, Lowell, \& Harris, 2018). Funds from the general student population and the government are often claimed by other areas. According to the authors, students who prefer the flexibility of taking online courses are willing to pay this extra fee. The institution can decide to access an online learning fee or a higher online tuition rate, which could serve as direct source of funds to e-learning centers on campus. It is near to impossible to reassign such funds to other areas. The institution receiving such funds would have the capacity to run e-platforms effectively.

Motivation Incentives and reward systems can motivate teachers and students to engage smoothly in e-learning (O'Doherty, et al., 2018). When teachers are rewarded on the time spent instructing students on e-platforms, they are motivated to spend extra time and dedicate more efforts in instructing students. In a study conducted in Russia, students decision to engage in online courses was due to available incentives (Markova, Glazkova, \& Zaborova, 2017). Incentives for teachers can be in the form of allowances and compensation. Students can be provided with free WIFI or subsidized cost of internet charge. This would encourage them to spend more time surfing for information on the internet, downloading course materials and uploading assignments. The government of Ghana can work with internet service providers in the country such as MTN and Vodaphone to provide internet access with high bandwidth to prevent them from withdrawing from e-platforms.

Supervision and evaluation An uninterrupted technical support is required from elearning users (teachers, students, and administrators) in addressing hardware and software problems associated with the computer application (Muhammad, Albejaidi, \& Akhtar, 2017). Rigorous supervision will help address glitches associated with eplatforms to ensure its continual functional. IT personnel and e-platform administrators can be assigned to monitor the progress of the online learning to identify and solve all hardware and software challenges. Academics involved in e-learning need assistance on shifting from the conventional mode of teaching and learning to a virtual teaching and learning environment (Donnelly and O'Rourke, 2007). This assistance can be provided by "e-champions" and ICT skilled personnel hired by the school. The authors mentioned that feedback of users on e-platforms are also essential for evaluating the success of e-learning, and this can inform school leaders on what to include in subsequent workshops for e-learning users. Also, using data derived from users of eplatforms will help the administrators and designers of the e-platform on how to structure the platform to meet students' needs and the unique culture of the institution.

Blended learning Picciano (2009) define blended learning as a combination of both online and face-to-face interaction. Response from the participants suggests that a blended learning approach could help address the differences among students. Picciano 
also mentioned that a blended learning approach could mitigate the challenge associated with geographical distance. Students who are far away from their institutions and prefer an online mode of delivery can learn from home through their e-learning platforms while those who prefer the traditional face-to-face interaction can learn at the classroom. Onguko (2014) believes that a blended mode of delivery is more ideal for universities who are not yet ready for only online learning. The author indicated that some universities in Kenya incorporated a face-to-face session in their virtual classes to address some difficulties connected with online learning.

\subsection{Conceptual model for emergency E-leaning course creating and submission}

The model serves as a framework for universities and academic institutions for an emergency transition to e-learning. This is adapted from Texas Tech University Health Science Center El Paso (TTUHSC EP) in their response to rapid transition to e-learning during the novel coronavirus pandemic (Mulla et al., 2020). Quality e-learning programs require time and unprecedented efforts to ensure successful implementation. The model suggests that for successful implementation and sustenance of e-learning programs, school leaders must first inform faculty leaders about available resources and the best method to ensure the transition; a simulation course should be created, faculty staffs need to be trained and assisted, as well as soliciting their feedback and suggestions; the course can then be submitted; an e-learning compliance committee (eLCC) should be set up for peer evaluation and for acquiring copyright permissions to keep the e-learning platform functioning (Fig. 1).

\section{Theoretical and practical implications}

The paper adds value to prior literature on ICT and online learning by first identifying the challenges associated with online learning in the developing context like Ghana during the COVID-19 pandemic. The study concluded by highlighting on some practical strategies for the adoption and usage of online learning in institutions in developing countries new to online learning. Findings from the study suggest that the

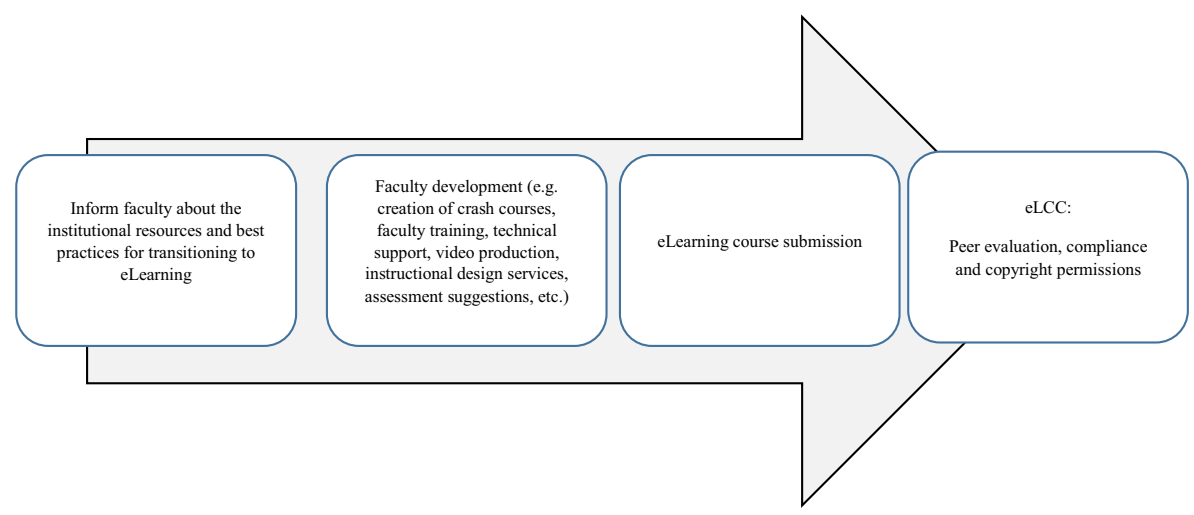

Fig. 1 An adapted conceptual model for creating and submission of e-learning course; Mulla et al. (2020) 
online learning in Ghana is fraught with a lot of challenges apart from high cost and infrastructure (Asunka, 2008; Bean, et al., 2019; Cradler \& Bridgforth, 2002; Turk \& Cherney, 2016). To address the problem of cost, school leaders are encouraged to establish e-learning centers which can generate funds solely for the purpose of online learning. Also, the limited amount of electric supply for e-learning activities can be mitigated by using affordable solutions like solar power gadgets, biomass, and humanpowered electricity which are readily accessible in the country. Again, school leaders are to employ recreational approaches like the use of social media and games to increase the self-efficacy of students for online learning. Collaborative e-learning for teachers and recreational approaches are essential for fostering acceptance of e-learning by both faculty staffs and students. In addition, to effectively develop an e-platform tailored to the needs users, a user-need analysis has to be performed to know individual preferences and need. The university administration also has to set up professional training programs for teachers to improve their digital literacy. Courses needed to improve students' IT skills can be mounted during the first year at school or during the few weeks of orientation. Moreover, because of geographical distance and individual learning styles and behavior, a blended mode of delivery is preferable such that students can choose either a face-to-face session or an online mode of delivery. It was also identified that the motivation of teachers and students is integral for smooth online learning. School leaders should motivate teachers and students in the form of incentives, allowances, free WIFI and subsidized cost of data bundle. The school administrators can laisse together with the government to employ mobile technologies to replace the high cost of laptops. Furthermore, because e-learning often experience hardware and software issues, school administrators should put in place a team of experts and technical resources for routine supervision and the evaluation of the elearning program. Overall, findings of the study provide novel insights for educators and policymakers for the transition and usage of e-learning in the and post COVID-19 pandemic.

\section{Conclusion/Reccomendations for future research}

Despite the significant investment of most low-income countries such as Ghana in ICT, challenges such as access to ICT, reluctance by both teachers and students to use ICT, network and electricity issues still persists in Ghana. In lieu of the online learning activity taking place in most institutions in Ghana, the study revisits how ICT is fundamental to online learning and education in general. The principal objective of the study was identify possible solutions to some perceived barriers in e-learning and ICT integration in Ghana. Findings from the study suggests that access to ICT resources in Ghanaian schools is still a challenge. As a result, students perceived the online learning is not effective. According to the students, although the online learning is a good initiative, they prefer the traditional approach as opposed to the online learning, which is fraught with a lot of challenges. The lack of social interactions, poor communication, and poor students' outcomes were associated with the perceived ineffectiveness of the e-learning. The students cited a lack of ICT tools, internet, electricity as some of the barriers to online learning. Most of the students interviewed did not have prior exposure to online learning or using ICT tools to study. The students 
believed that orientation of both teachers and students on ICT for online learning, motivation, and school leadership practices affect the integration of ICT in education. The usage of solar power gadgets, the establishment of e-learning centers, acquiring funds from e-learning centers, adoption of blended learning, and providing infrastructural support such as using mobile technologies to replace the cost of procuring laptops are some of the listed strategies for educators to consider. ICT plays an integral role in education and the economy of any country, help in resolving the barriers associated with online learning, and facilitates the successful integration of ICT in education to enhance online learning. Dessalegn \& Dagmawi (2018) opined that developed countries benefited from the integration of ICT in education, unlike developing countries. The fact that higher education plays a vital role in the success of students and countries but there is limited access in Africa, online learning can help bridge this gap (Lembani, Gunter, Breines, \& Dalu, 2019). It is therefore vital for stakeholders in education to integrate ICT in education in Ghana, and implement realistic and rigorous ICT policies to ensure effective online learning where the needs of both urban, urban poor, and rural students are taken into consideration. The author recommend that future research examine the effectiveness, challenges of e-learning and ICT integration in other contexts support their findings in literature with empirical evidence using a quantitative approach with a large sample.

\section{Limitations}

The sample of the study is very small, which makes it difficult for generalization. The study only focused on students' perspectives of the online learning in Ghana without including the voices of teachers instructing students. Also, the participants of the study were only from tertiary institutions in Ghana without including pre-tertiary students who were also taking the part of the e-learning.

Acknowledgements The author sincerely expresses his special thanks to Professor Yu Zeyuan (Southwest University, China), Robert Kyei (Nsawam Presby Basic School), and Edna Agyemang (University of Ghana).

\section{References}

Addah, K., Kpebu, D., \& Kwapong, O. A. (2012). Promoting e-learning in distance education programs in an African Country. InTech. Retrieved from http:/www.intechopen.com/books/e-learning-long-distanceand-lifelong-perspectives/promoting-e-learning-in-distance-education-programmes-in-an-Africancountry.

Agustini, K. (2017). The adaptive Elearning system design: Student learning style trend analysis. In 2nd International Conference on Innovative Research Across Disciplines (ICIRAD 2017) (pp. 50-54). Atlantis Press.

Agyemang, B. K., \& Dadzie, P. (2010). Providing information communication technology support to distance education students: A case of the University of Ghana, Legon. Turkish Online Journal of Distance Education, 11(3), 129-145.

Aksal, F. A., \& Gazi, Z. A. (2015). Examination on ICT integration into special education schools for developing countries. The Turkish Online Journal of Educational Technology, 14(3), 70-72.

Alhabeeb, A., \& Rowley, J. (2018). E-learning critical success factors: Comparing perspectives from academic staff and students. Computers \& Education, (127), 1-12. https://doi.org/10.1016/j.compedu.2018.08.007. 
Aljaraideh, Y., \& Bataineh, K. A. (2019). Jordanian students' barriers of utilizing online learning: A survey study. International Education Studies, 12(5), 99-108.

Alt, D. (2018). Science teachers' conceptions of teaching and learning, ICT efficacy, ICT professional development and ICT practices enacted in their classrooms. Teaching and Teacher Education, 73, 141-150. https://doi.org/10.1016/j.tate.2018.03.020.

Amanortsu, G., Dzandu, M. D., \& Asabere, N. Y. (2013). Towards the access to and usage of information and communication technology (ICT) in polytechnic education. International Journal of Computer Applications, 66(1), 23-33.

Antwi, S., Bansah, A. K., \& Franklin, T. (2018). The information technology challenge in teaching senior high school geography in Ghana. Issues and Trends in Educational Technology, 6(1), 16-37.

Anyorigya, D. A. (2020). COVID-19: Halt challenge-ridden online learning in universities - NUGS to Government. Retrieved from citinews: https:/citinewsroom.com/2020/04/covid-19-halt-challengeridden-online-learning-in-universities-nugs-to-government/

Arthur-Nyarko, E., \& Kariuki, M. G. (2019). Learner access to resources for eLearning and preference for eLearning delivery mode in distance education programmes in Ghana. International Journal of Educational Technology, 6(2), 1-8.

Asante, J. N. (2014). The state of ICT integration in the early years in Ghana schools. Literacy Information and Computer Education Journal, 3(1), 1751-1757.

Asunka, S. (2008). Online learning in higher education in sub-Saharan Africa: Ghanaian University students' experiences and perceptions. International Review of Research in Open and Distance Learning, 9(3), 123. https://doi.org/10.19173/irrodl.v9i3.586.

Avgerou, C. (2008). Information systems in developing countries: A critical research review. Journal of Information Technology, 23, 133-146. https://doi.org/10.1057/palgrave.jit.2000136.

Ayebi-Arthur, K., Aidoo, D. B., \& Wilson, K. B. (2009). A study on the use of the internet in senior high schools in the Cape Coast metropolis of Ghana. Ghana Journal of Education and Teaching, 8, 1-16.

Bacow, L. S., Bowen, W. G., Guthrie, K. M., Lack, K. A., \& Long, M. P. (2012). Barriers to Adoption of Online Learning Systems in U.S. Higher Education. New York: Ithaka S+R. Retrieved from https://sr. ithaka.org/wp-content/uploads/2015/08/barriers-to-adoption-of-online-learning-systems-in-us-highereducation.pdf

Bean, M. V., Aldredge, T., Chow, K., Fowler, L., Guaracha, A., McGinnis, T., et al. (2019). Effective practices for online tutoring. Sacramento: Academic Senate for California Community Colleges.

Bingimlas, K. A. (2009). Barriers to the successful integraton of ICT in teaching and learning environments: A review of the literature. Eurasia Journal of Mathematics, Science \& Technology, 5(3), 235-245.

Birch, A., \& Irvine, V. (2009). Preservice teachers' acceptance of ICT integration in the classroom: Applying the UTAUT model. Educational Media International, 46(4), 295-315.

Boni, R. K. (2018). The use of ICT for teaching and learning in senior high schools in Ghana: A study of Nungua and Presbyterian, Teshie. Ghana: University of Ghana, Legon.

Buabeng-Andoh, C. (2012). Factors influencing teachers' adoption and integration of information and communication technology into teaching: A review of the literature. International Journal of Education and Development using Information and Communication Technology, 8(1), 136-155.

Carr-Chellman, A. A. (2005). Global perspectives on E-learning: Rhetoric and reality. Thousand Oaks: Sage Publications.

Cradler, J., \& Bridgforth, E. (2002). Recent research on the effects of technology on teaching and learning. Retrieved from http://www.oten.info/conferences/jukes/research.pdf

Creswell, J. W. (2018). Research design: qualitative, quantitative, and mixed methods approaches (5th ed.). Los Angeles: SAGE.

Crisolo, N. A. (2018). Sharpening education through the use of information technology and communication technology. SDO Quezon: Sta. Catalina National High School.

Cromwell, A. (2020). Education Ministry set to release online learning platform for Senior High Schools. Retrieved from Myjoyonline: https:/www.myjoyonline.com/news/national/education-ministry-set-torelease-online-learning-platform-for-senior-high-schools/

David, N. (2009). The impact of ICT in rural education: Case study- Enugu state. Nigerian Journal of Technology, 28(2), 71-79.

de la Varre, C., Keane, J., \& Irvin, M. J. (2010). Enhancing online distance education in small rural US schools: A hybrid, learner-centred model. ALT-J, 18(3), 193-205.

DePaul, K. (2020). Can online learning mitigate rural schools' biggest challenges? Retrieved from https:// www.gettingsmart.com/2020/02/can-online-learning-mitigate-rural-schools-biggest-challenges/

Dessalegn, M., \& Dagmawi, L. (2018). The promises and challenges of ICT-pedagogy integration in developing countries: The case of Ethiopia. International Journal of Education, 1(7), 6-8. 
Donnelly, R., \& O'Rourke, K. C. (2007). What now? Evaluating eLearning CPD practice in Irish third-level education. Journal of Further and Higher Education, 31(1), 31-40. https://oi.org/10.1080/ 03098770601167864.

Education Sector Performance Report. (2010). Accra: Ghana Ministry of Education.

Education Sector Performance Report. (2012). Accra: Ghana Ministry of Education.

Flavell, H., Harris, C., Price, C., Logan, E., \& Peterson, S. (2019). Empowering academics to be adaptive with eLearning technologies: An exploratory case study. Australasian Journal of Educational Technology, 35(1), 1-15. https://doi.org/10.14742/ajet2990.

Forsyth, H., Pizzica, J., Laxton, R., \& Mahony, M. J. (2010). Distance education in an era of eLearning: Challenges and opportunities for a campus-focused institution. Higher Education Research and Development, 29(1), 15-28. https://doi.org/10.1080/07294360903421350.

Gaffas, Z. M. (2019). Students' perceptions of the impact of EGP and ESP courses on their English language development: Voices from Saudi Arabia. Journal of English for Academic Purposes, 42, 1-13. https://doi. org/10.1016/j.jeap.2019.100797.

Grabe, M., \& Grabe, C. (2007). Integrating technology for meaningful learning. Boston: Houghton Mifflin.

Hachey, J., \& Lachapelle, N. (2018). Trousse des Superhéros TÉLUQ : un outil pour les professeurs. In Elearning Superheroes: A Professor's Handbook. Université TÉLUQ, Québec, Canada. Presented at Online Learning Global Summit \& EdTech Expo 2018, Toronto. Retrieved from https://www.teluq.ca/ superheros/

Haji, S. A., Moluayonge, G. E., \& Park, I. (2017). Teachers' use of information and communications technology in education: Cameroon secondary schools perspectives. The Turkish Online Journal of Educational Technology, 16(3), 147-153.

Hamajoda, A. F. (2018). Towards a topology for ICT \& E-learning in Nigerian rural public primary schools.

Heeks, R. (2008). Priorities in mobiles-for-development research. Sweden: Proceedings of M4D 2008, Karlstad University.

Heeks, R. (2012). Deriving an ICT4D research agenda. Journal of Information Technology, 27(4), 339-341. https://doi.org/10.1057/jit.2012.31.

Hew, K., \& Brush, T. (2007). Integrating technology into k-12 teaching and learning: Current knowledge gaps and recommendations for future research. Educational Technology Research and Development, 55(3), 223-252.

Hong, J. E. (2016). Social studies teachers' views of ICT integration. Review of International Geographical Education Online, 6(1), 32-48.

International Telecommunication Union. (2014). Measuring the information society-The ICT development index. Geneva: International Telecommunication Union.

International Telecommunication Union. (2016). Measuring the information society-The ICT development index. Geneva: International Telecommunication Union.

Ivala, E. (2013). ICEL2013-proceedings of the 8th international conference on e-learning: ICEL 2013. Academic Conferences Limited.

Jimba, D., \& Ogundele, M. O. (2015). Power and energy generation as a threat for developing virtual classroom in Nigerian distance education. International Centre for Science, Humanities \& Education Research, 1(2), 63-69.

Johnston, N. (2020). The shift towards digital literacy in Australian university libraries: Developing a digital literacy framework. Journal of the Australian Library and Information Association, 69(1), 93-101. https://doi.org/10.1080/24750158.2020.1712638.

Jones, G. R. (1997). Cyberschools. Englewood: Jones Digital Century.

Judge, M. (2013). Mapping out the ICT integration terrain in the school context: Identifying the challenges in an innovative project. Irish Educational Studies, 32(3), 309-333.

Khan, B. (1997). Web-based instruction: What is it and why is it? In B. H. Khan (Ed.), Web-based instruction (pp. 5-18). Englewood Cliffs: Educational Technology Publications.

Kizilcec, R. F., \& Halawa, S. (2015). Attrition and achievement gaps in online learning. In Proceedings of the Second (2015) ACM Conference on Learning@ Scale (pp. 57-66). ACM.

Law, N., Pelgrum, W. J., \& Plomp, T. (2008). Pedagogy and ICT use. Dordrecht: Springer. https://doi.org/10. 1007/978-1-4020-8928-2.

Lembani, R., Gunter, A., Breines, M., \& Dalu, M. T. (2019). The same course, different access: The digital divide between urban and rural distance education students in South Africa. Journal of Geography in Higher Education, 44(1), 70-84. https://doi.org/10.1080/03098265.2019.1694876.

Liebenberg, H., Chetty, Y., \& Prinsloo, P. (2012). Student access to and skills in using technology in an open and distance learning context. The International Review of Research in Open Distance Learning, 13(4), $250-268$. 
Luongo, N. (2018). An examination of distance learning faculty satisfaction levels and self-perceived barriers. Journal of Educators Online, 15(2), 1-12.

Markova, T., Glazkova, I., \& Zaborova, E. (2017). Quality issues of online distance learning. Procedia Social and Behavioral Sciences, 237, 685-691. https://doi.org/10.1016/j.sbspro.2017.02.043.

Mereku, D. K., Yidana, I., Hordzi, W., Tete-Mensah, I., \& Williams, J. B. (2009). Executive summary: Ghana-pan African report on technology integration. Ghana: University of Education, Winneba. Retrieved from http://www.ernwaca.org/panaf/pdf/phase-1/Ghana-PanAf_Report

Ministry of Education. (2015). ICT in education policy. Accra.

Morrison, D. (2003). E-learning strategies: How to get implementation and delivery right first time. England: John Wiley \& Sons Ltd.

Mtebe, J. S., \& Raisamo, R. (2014). Investigating perceived barriers to the use of open educational resources in higher education in Tanzania. The International Review of Research in Open and Distance Learning, $15(2), 43-65$.

Mubashir-Ahmed, I. B. (2009). An assessment of the ICT situation in senior high schools in the upper west region of Ghana. University of Capecoast, Ghana.

Muhammad, G., Albejaidi, F. M., \& Akhtar, R. (2017). Challenges in development of eLearning systems in higher education of the developing countries. London Journal of Research in Humanities and Social Sciences, 17(2), 13-32.

Mulla, Z. D., Osland-Paton, V., Rodriguez, M. A., Vazquez, E., \& Plavsic, S. K. (2020). Novel coronavirus, novel faculty development programs: Rapid transition to eLearning during the pandemic. Journal of Perinatal Medicine, 48(5), 446-449. https://doi.org/10.1515/jpm-2020-0197.

Ngai, C. S., Lee, W. M., Ng, P. P., \& Wu, D. D. (2018). Innovating an integrated approach to collaborative eLearning practices in higher education: The case study of a corporate communication e-platform. Studies in Higher Education, 44(11), 1990-2010. https://doi.org/10.1080/03075079.2018.1482266.

Nowell, S. D. (2014). Using disruptive technologies to make digital connections: Stories of media use and digital literacy in secondary classrooms. Educational Media International, 51(2), 109-123. https://doi. org/10.1080/09523987.2014.924661.

O’Doherty, D., Dromey, M., Lougheed, J., Hannigan, A., Last, J., \& McGrath, D. (2018). Barriers and solutions to online learning in medical education - An integrative review. BMC Medical Education, 18(130), 1-11. https://doi.org/10.1186/s12909-018-1240-0.

Olesova, L., Yang, D., \& Richardson, J. C. (2011). Cross-cultural differences in undergraduate students' perceptions of online barriers. Journal of Asynchronous Learning Networks, 15(3), 68-80.

Onguko, B. B. (2014). JiFUNzeni: A blended learning approach for sustainable teachers' professional development. The Electronic Journal of e-Learning, 12(1), 77-88.

Osubor, V. I., \& Chiemeke, S. C. (2015). E-learning functional model: A technology-based teaching method for providing access to sustainable quality education. African Journal of Computing \& ICT, 8, 127-132.

Picciano, A. (2009). Blending with Purpose: The Multimodal Model. Journal of Asynchronous Learning Networks, 13(1), 7-18. https://doi.org/10.24059/olj.v13i1.1673.

Piña, A. A., Lowell, V. L., \& Harris, B. R. (2018). Leading and managing e-learning: What the e-learning leader needs to know. Gewerbestrasse: Springer Nature.

Queiros, D. R., \& de Villiers, M. R. (2016). Online learning in a south African higher education institution: Determining the right connections for the student. The International Review of Research in Open and Distance Learning, 17(5).

Sarkar, S. (2012). The role of information and communication technology (ICT) in higher education for the 21 stcentury. The science probe, 1(1), 30-41.

Sharpe, R., \& Benfield, G. (2012). Institutional strategies for supporting learners in a digital age. Enhancing Learning in the Social Sciences, 4(2), 1-17. https://doi.org/10.11120/elss.2012.04020004.

Singh, V., \& Thurman, A. (2019). How many ways can we define online learning? A systematic literature review of definitions of online learning (1988-2018). American Journal of Distance Education, 33(4), 289-306.

Sinha, E., \& Bagarukayo, K. (2019). Online education in emerging knowledge economies: Exploring factors of motivation, de-motivation and potential facilitators; and studying the effects of demographic variables. International Journal of Education and Development using Information and Communication Technology, 15(2), 5-30.

Solangi, Z. A., Shahrani, F. A., \& Pandhiani, S. M. (2018). Factors affecting successful implementation of eLearning: Study of colleges and institutes sector RCJ Saudi Arabia. International Journal of Emerging Technologies in Learning, 13(6), 223-230. https://doi.org/10.3991/ijet.v13i06.8537.

Srichanyachon, N. (2014). The barriers and needs of online learners. Turkish Online Journal of Distance Education, 15(3), 50-59. 
The Council of Independent Colleges. (2016). High-tech or high-touch? Online learning and independent higher education. Washington, DC. Retrieved from www.cic.edu/ResearchFuture.

Tondeur, J., Devos, G., van Houtte, M., van Braak, J., \& Valcke, M. (2009). Understanding structural and cultural school characteristics in relation to educational change: The case of ICT integration. Educational Studies, 35, 223-235.

Turk, S. E., \& Cherney, I. D. (2016). Perceived online education barriers of administrators and faculty at a U.S. university in Lebanon. Creighton Journal of Interdisciplinary Leadership, 2(1), 15-31.

UNESCO. (2012). ICT-enhanced teacher standards for Africa (ICTeTSA). Addis Ababa: UNESCO-IICBA.

UNESCO. (2020). COVID-19 Educational Disruption and Response. Retrieved from https://en.unesco.org/ covid19/educationresponse

Uren, M., \& Uren, J. (2009). eTeaching and eLearning to enhance learning for a diverse cohort in engineering education. Engineering Education, 4(2), 84-90. https://doi.org/10.11120/ened.2009.04020084.

Waluyo, B. (2019). The effects of ICT on achievement: Criticizing the exclusion of ICT from World Bank's education sector strategy 2020. Malaysian Online Journal of Educational Technology, 7(2), 71-87. https://doi.org/10.17220/mojet.2019.02.005.

Wyche, S. P., \& Murphy, L. L. (2013). Powering the cellphone revolution: Findings from mobile phone charging trials in off-grid Kenya. CHI '13: Proceedings of the SIGCHI Conference on Human Factors in Computing Systems, (pp. 1959-1968). https://doi.org/10.1145/2470654.2466260.

Publisher's note Springer Nature remains neutral with regard to jurisdictional claims in published maps and institutional affiliations. 